\title{
Exposure to Airborne Particulate Matter: An Additional Risk Factor for Metabolic Syndrome in Saudi Arabia
}

\author{
Mansour A. Alghamdi \\ Department of Environmental Sciences, Faculty of Meteorology, \\ Environment and Arid Land Agriculture, King Abdulaziz University, \\ Jedahha, Saudia Arabia
}

\begin{abstract}
Metabolic syndrome is a serious problem in Saudi Arabia. It has been attributed mainly to life style. Exposure to airborne particulate matter is a subject of concern in Jeddah. The present study aimed to find a possible association of metabolic syndrome prevalence with levels of particulate matter and their elemental constituents. The study was conducted in two districts of Jeddah, Al Nuzlah and Al Rehab. PM 10 and PM $\mathrm{PM}_{2.5}$ were measured in each district as well as their elemental composition. Metabolic syndrome was defined by the presence of three components: hyperglycemia, hypertension and obesity. Al Nuzlah district showed higher prevalence of metabolic syndrome, together with higher levels of $\mathrm{PM}_{2.5}$, nickel and cadmium. It can be concluded that exposure to particulate matter may be considered as an additional risk factor for metabolic syndrome.
\end{abstract}

Keywords: Particulate Matter, Metabolic Syndrome, Jeddah, Elemental Composition, Risk Factors.

\section{Introduction}

The combination of interrelated metabolic abnormalities predisposing individuals to cardiovascular diseases is usually referred to as metabolic syndrome (MetS) (Lindsay and Howard, 2004; Alberti, et al., 2005 and Suzuki, et al., 2008). Presence of any three of five risk factors (abdominal obesity, elevated triglycerides, reduced high-density lipoprotein cholesterol, elevated blood pressure and elevated fasting glucose) constitutes a diagnosis of MetS (Albert, et al., 2009). MetS is a risk factor not only for cardiovascular diseases, but also, for various cancers mainly endometrial (Rosato, et al., 2011) and colorectal (Pelucchi, et al., 2010) cancers.
Increased oxidative stress, through increased reactive oxygen species (ROS) levels, was found to play a central role in metabolic syndrome and its component pathologies (Hutcheson and Rock, 2012): obesity (Furukawa, et al., 2004 and Montero, et al., 2012), hyperglycemia (De Mattia, et al., 2008), dyslipidemia (Zelzer, et al., 2011), and hypertension (Ward, et al., 2004 and Wang, et al., 2009).

Association between exposure to airborne particulate matter (PM) and health is well established. Particle size: fine particles $\left(\mathrm{PM}_{2.5}\right)$ and ultrafine particles (PM1.0), and their metal content ( $\mathrm{Ni}, \mathrm{V}, \mathrm{Br}, \mathrm{Cr}, \mathrm{As}, \mathrm{Mn})$, were found to play a critical role in the $\mathrm{PM}$ 
toxicity (Araujo and Nel, 2009, Zanobetti, et al.,2009 and Bell, 2012).

PM exposure was found to promote the development of the metabolic syndrome (Hutcheson and Rock, 2012), or its components: diabetes (Gonzalez, et al., 2013 and Chen, et al., 2013a) and hypertension (Chen, et al., 2013b), increased oxidative stress being the fundamental mechanism (Chuang, et al., 2007 and Ghio, et al., 2012). Metal-containing inhalable nanoparticles can penetrate the alveolar-septal barrier and generate oxidative stress both via activation of alveolar macrophage and systemic vascular oxidases including $\mathrm{NAD}(\mathrm{P}) \mathrm{H}$, mitochondrial and xanthine oxidases (Zanobetti, et al., 2009). Moreover, metals directly support electron transport to generate oxidants and also diminish levels of antioxidants (Ghio, et al., 2012). Some metals contribute to MetS through their endocrine-disrupting properties (De Coster and van Laberecke, 2012).

People with MetS exposed to particulate matter (PM) showed greater susceptibility to PM-associated cardiac effects. Autonomic dysfunction (Chen and Schwartz, 2008) and inflammatory responses (Park, et al., 2010) were two suggested mechanisms.

The prevalence and characteristics of MetS in Saudi Arabia was studied as early as 2002. These studies reported different prevalence depending on different definitions: World Health Organization (WHO), National Cholesterol Education Program (NCEP), Adult Treatment Panel III (ATP III), and International Diabetes Federation (IDF). The overall MetS prevalence ranged from 16.7\% to $40 \%$ (Akbar, 2002; Al-Qahtani and Imtiaz, 2005; Al-Nozha, et al., 2005; Al-Qahtani, et al., 2006; Barrimah, et al., 2009; Al-Daghri, et al., 2010, Al-Zahrani, et al., 2012; Bahijri, et al., 2013 and Bahijri and Al-Raddadi, 2013).
The most common factors were hypertension, low HDL cholesterol, and abdominal obesity.

Exposure to $\mathrm{PM}_{10}$ collected from Jeddah, Saudi Arabia, was found to induce cholesterol and lipid metabolism genes both in vitro (Sun, et al., 2012) and in vivo (Brocato, et al., 2014). This is the first study trying to point out that in addition to the classical risk factors, air pollution is an important additional risk factor for MetS.

\section{Materials and Methods Study Population}

Due to the anticipated differences in the socioeconomic and pollution levels between South and North Jeddah, the present study was carried out in two districts, Al Nozlah district representing South Jeddah, and Al Rehab district representing North Jeddah. This study was conducted by interviewing individuals visiting one mega-mall in each district. A team was present in each mall during weekends' nights, from June 2011 to September 2011. Participants were selected based on their willingness. The only criterion for exclusion was living in the area (north or south) for less than 15 years. Before interviewing, one of the researchers explained the purpose of the study and the content of the questionnaire, which did not require the participant to be identified by name. Therefore, confidentiality was strictly maintained in all the completed questionnaires. An informed verbal consent was obtained from each participant. Participants were informed about the results of their examination in situ.

The questionnaire included age, occupation, home address, past history of diabetes, hypertension and any other chronic diseases, smoking habits, physical activity and vegetables and fruits consumption. After the interview, the participant's body weight and height were recorded in light clothes and no 
shoes. Body mass index (BMI) was calculated according to the formula: $\mathrm{BMI}=$ mass $(\mathrm{kg}) /(\text { height }(\mathrm{m}))^{2}$. Concerning the smoking history, Indrayan's smoking index was calculated. It accounts for different characteristics like cigarettes smoked per day, duration of smoking, passive smoking, smoking of filter cigarettes or water pipes, age at start and duration elapsed since quitting by ex-smokers (Aslam, et al., 2011).

An accurate blood pressure measurement was done. Each participant was asked to sit comfortably for $5 \mathrm{~min}$ prior to the examination, during which his back was fully supported. Three measurements were taken with 5 minutes interval and their mean recorded. Random capillary blood sugar levels were measured by finger pricks. Participants reporting use of anti-hypertensive drugs were considered hypertensive regardless of their blood pressure reading. The same was applied to diabetic patients.

Participants reporting use of antihypertensive drugs were considered hypertensive regardless of their blood pressure reading. Random capillary blood sugar levels were measured by finger pricks.

Metabolic syndrome cases were subjects having all three metabolic syndrome components, i.e., Capillary blood sugar: > 130, systolic blood pressure: $>130$ \&/or diastolic blood pressure: $>85$, BMI: for males $>29.0$ and for females: $>29.9$. Free subjects were those having none of the aforementioned MetS components.

\section{Air Sample Collection}

Two sampling sites were selected, one located in Al Nozlah district representing south Jeddah, the other in Al Rehab district in north Jeddah. They was set at a height of 9 meters above the ground level on the roof of a building in each district. Using $\mathrm{PM}_{2.5}$ and $\mathrm{PM}_{10}$ samplers (Automated Cartridge
Collector Unit (ACCU) Sampler), the samples were collected using a calibrated vacuum pump (Gast, USA) to draw air at a rate of 10 $\mathrm{L} / \mathrm{min}$, and daily 24 hour samples were collected on Teflon filters (GelmanTeflo, 37 $\mathrm{mm}, 0.2 \mu \mathrm{m}$ pore-size) from midnight to midnight. The flow rates of the vacuum pump were calibrated before and after each sampling session. Samples were collected from June 2011 to September 2011 at a rate of three times per week, once on a weekend day and twice on weekdays.

\section{Gravimetric and Elemental Analysis}

The detailed description for gravimetric and elemental analysis of samples via energy dispersive X-ray fluorescence (ED-XRF) is provided in Maciejczyk and Chen (2005). In short, filter masses were measured on a microbalance (model MT5, Mettler-Toledo Inc., Highstown, NJ), and the samples were subsequently analyzed for it elements by nondestructive XRF (model EX-6600-AF, Jordan Valley) using two secondary fluorescers ( $\mathrm{Ti}$ and $\mathrm{Ge}$ ), and spectral software XRF2000v3.1 (U.S. EPA and ManTech Environmental Technology, Inc.). Concentrations of elements above detection limit were defined as 3 times of the uncertainty of the measurements $(3 \sigma)$.

\section{Statistical Analysis}

We first conducted $\chi 2$ tests to compare differences in distribution of selected population characteristics for the free subjects and the MetS cases between the two districts. Then, we applied the Wilcoxon-MannWhitney test for testing the significance when the median of the concentration of $\mathrm{PM}_{10}$ and their elemental constituents were compared. Significance was accepted at $\mathrm{p}<0.05, \mathrm{p}<0.01$. All analyses were completed using SAS (V.9.3; SAS Institute Inc, Cary, North Carolina, USA). 


\section{Results}

Table 1 shows the distribution of metabolic syndrome cases and free subjects by selected population characteristics. The percentage of cases with metabolic syndrome was significantly higher $(\mathrm{P}<0.01)$ in $\mathrm{Al}$ Nuzlah districts reaching $49.0 \%$ versus $18.6 \%$ in $\mathrm{Al}$ Rehab district. There were no significance differences in sex, age, BMI, smoking, educational level, regular exercise performing and vegetable and fruit consumption between the two studied districts.

Table 1. Distribution of metabolic syndrome cases and free subjects by selected population characteristics in the two districts. (Al Nuzlah: $n=100$, Al Rehab: $n=145$ ).

\begin{tabular}{|c|c|c|c|c|c|}
\hline & & \multicolumn{2}{|c|}{ Free subjects } & \multicolumn{2}{|c|}{ MetS cases } \\
\hline & & Al Nuzlah & Al Rehab & Al Nuzlah & Al Rehab \\
\hline & & $\mathrm{n}(\%)$ & $\mathrm{n}(\%)$ & $\mathrm{n}(\%)$ & $\mathrm{n}(\%)$ \\
\hline \multicolumn{2}{|l|}{ Total } & $51(51.0 \%)$ & $118(81.4 \%)$ & $49(49.0 \%)^{* *}$ & $27(18.6 \%)$ \\
\hline \multirow{2}{*}{ Sex } & Male & $57(70.4 \%)$ & $48(64.9 \%)$ & $15(78.9 \%)$ & $37(52.1 \%)$ \\
\hline & Female & $24(29.6)$ & $26(35.1 \%)$ & $4(21.1 \%)$ & $34(25.4 \%)$ \\
\hline \multicolumn{2}{|c|}{$\operatorname{Age}($ years $)($ Mean $\pm S D)$} & $24.06 \pm 6.23$ & $27.45 \pm 5.76$ & $41.21 \pm 9.87$ & $40.23 \pm 11.36$ \\
\hline \multicolumn{2}{|c|}{ BMI $\left(\mathrm{Kg} / \mathrm{m}^{2}\right)($ Mean $\pm \mathrm{SD})$} & $23.02 \pm 2.16$ & $24.12 \pm 2.82$ & $33.55 \pm 2.99$ & $34.17 \pm 3.16$ \\
\hline \multirow{2}{*}{ Smoking } & Non Smokers & $70(86.4 \%)$ & $60(81.1 \%)$ & $12(63.2 \%)$ & $43(60.6 \%)$ \\
\hline & Smokers & $11(13.6 \%)$ & $14(18.9 \%)$ & $7(36.8 \%)$ & $28(39.4 \%)$ \\
\hline \multirow{2}{*}{ Educational level } & Undergraduate & $53(65.4 \%)$ & $39(52.7 \%)$ & $11(57.9 \%)$ & $44(61.9 \%)$ \\
\hline & Graduate & $28(34.6 \%)$ & $35(47.3 \%)$ & $8(42.1 \%)$ & $27(38.1 \%)$ \\
\hline \multirow{2}{*}{ Regular exercise } & Yes & $29(35.8 \%)$ & $24(32.4 \%)$ & $4(21.1 \%)$ & $18(25.4 \%)$ \\
\hline & No & $52(64.2 \%)$ & $50(67.6 \%)$ & $15(78.9 \%)$ & $53(74.6 \%)$ \\
\hline \multirow{2}{*}{$\begin{array}{c}\text { Vegetable and } \\
\text { fruit consumption }\end{array}$} & $<5$ servings/ day & $75(92.6 \%)$ & $65(87.8 \%)$ & $16(84.2 \%)$ & $61(85.9 \%)$ \\
\hline & $5+$ servings/day & $6(7.4 \%)$ & $9(12.2 \%)$ & $3(15.8 \%)$ & $10(14.1 \%)$ \\
\hline
\end{tabular}

$* * \mathrm{p}<0.01$

The concentration of $\mathrm{PM}_{10}$ and their elemental constituents $(\mu \mathrm{g} / \mathrm{m} 3)$ in the two districts, Al Nuzlah and Al Rehab are presented in Table 2. When the medians were compared, no statistically significant differences could be detected between the median levels of total $\mathrm{PM}_{10}$ or their elemental constituents, between the two districts. 
Table 2. Concentration of $\mathrm{PM}_{10}$ and their elemental constituents $(\mu \mathrm{g} / \mathrm{m3})$ in the two districts, Al Nuzlah and Al Rehab.

\begin{tabular}{|l|c|c|c|c|c|c|}
\hline \multicolumn{5}{|c|}{ Al Nozlah } & \multicolumn{3}{c|}{ Al Rehab } \\
\hline$\mu \mathrm{g} / \mathrm{m}^{3}$ & Mean & SD & Median & Mean & SD & Median \\
\hline Total & 73.5140 & 10.1338 & 71.7015 & 68.9484 & 20.4789 & 60.2780 \\
\hline $\mathrm{Ti}$ & 0.1538 & 0.0280 & 0.1622 & 0.1977 & 0.0790 & 0.1862 \\
\hline $\mathrm{V}$ & 0.0326 & 0.0096 & 0.0383 & 0.028 & 0.0058 & 0.0226 \\
\hline $\mathrm{Cr}$ & 0.0066 & 0.0011 & 0.0071 & 0.0059 & 0.0023 & 0.0053 \\
\hline $\mathrm{Co}$ & 0.0285 & 0.0058 & 0.0284 & 0.0252 & 0.0058 & 0.0266 \\
\hline $\mathrm{Ni}$ & 0.0099 & 0.0027 & 0.0111 & 0.0065 & 0.0025 & 0.0065 \\
\hline $\mathrm{Ga}$ & 0.0013 & 0.0007 & 0.0016 & 0.0026 & 0.0021 & 0.0026 \\
\hline $\mathrm{Ge}$ & 0.0005 & 0.0005 & 0.0005 & 0.0024 & 0.0017 & 0.0022 \\
\hline $\mathrm{As}$ & 0.0041 & 0.0044 & 0.0035 & 0.0100 & 0.0159 & 0.0029 \\
\hline $\mathrm{Se}$ & 0.0028 & 0.0003 & 0.0028 & 0.0036 & 0.0017 & 0.0039 \\
\hline $\mathrm{Rb}$ & 0.0025 & 0.0004 & 0.0026 & 0.0030 & 0.0014 & 0.0027 \\
\hline $\mathrm{Sr}$ & 0.0217 & 0.0034 & 0.0218 & 0.0232 & 0.0150 & 0.0183 \\
\hline $\mathrm{Cd}$ & 0.0766 & 0.0160 & 0.0741 & 0.0848 & 0.0272 & 0.0731 \\
\hline $\mathrm{Pb}$ & 0.0399 & 0.0445 & 0.0214 & 0.1005 & 0.1503 & 0.0197 \\
\hline
\end{tabular}

The concentration of $\mathrm{PM}_{2.5}$ and their elemental constituents $(\mu \mathrm{g} / \mathrm{m} 3)$ in the two districts, Al Nuzlah and Al Rehab are presented in Table 3. Comparing the medians revealed that the levels of total $\mathrm{PM}_{2.5}$, nickel and cadmium were significantly higher $(p<0.05)$ in Al Nozlah district. The rest of the elements did not show any significant difference between both districts. 
Table 3. Concentration of $\mathrm{PM}_{2.5}$ and their elemental constituents $(\mu \mathrm{g} / \mathrm{m3})$ in the two districts, Al Nuzlah and Al Rehab.

\begin{tabular}{|c|c|c|c|c|c|c|}
\hline \multicolumn{7}{|c|}{$\mathbf{P M}_{2.5}$} \\
\hline & \multicolumn{3}{|c|}{ Al Nozlah } & \multicolumn{3}{|c|}{ Al Rehab } \\
\hline$\mu \mathrm{g} / \mathrm{m}^{3}$ & Mean & SD & Median & Mean & SD & Median \\
\hline Total & 29.10 & 14.12 & $23.30 *$ & 18.04 & 3.95 & 17.12 \\
\hline $\mathrm{Ti}$ & 0.0112 & 0.0027 & 0.0119 & 0.0173 & 0.0143 & 0.0147 \\
\hline V & 0.0291 & 0.0098 & 0.0331 & 0.0150 & 0.0038 & 0.0147 \\
\hline $\mathrm{Cr}$ & 0.0018 & 0.0008 & 0.0014 & 0.0015 & 0.0010 & 0.0017 \\
\hline Co & 0.0054 & 0.0002 & 0.0054 & 0.0058 & 0.0023 & 0.0059 \\
\hline $\mathrm{Ni}$ & 0.0071 & 0.0023 & $0.0074 *$ & 0.0042 & 0.0009 & 0.0042 \\
\hline $\mathrm{Ga}$ & 0.0002 & 0.0002 & 0.0001 & 0.0020 & 0.0019 & 0.0013 \\
\hline $\mathrm{Ge}$ & 0.0007 & 0.0004 & 0.0006 & 0.0020 & 0.0017 & 0.0015 \\
\hline As & 0.0022 & 0.0019 & 0.0024 & 0.0078 & 0.0106 & 0.0025 \\
\hline $\mathrm{Se}$ & 0.0025 & 0.0007 & 0.0025 & 0.0031 & 0.0013 & 0.0024 \\
\hline $\mathrm{Rb}$ & 0.0016 & 0.0003 & 0.0016 & 0.0011 & 0.0006 & 0.0012 \\
\hline $\mathrm{Sr}$ & 0.0021 & 0.0007 & 0.0022 & 0.0018 & 0.0020 & 0.0014 \\
\hline $\mathrm{Cd}$ & 0.0044 & 0.0037 & $0.0039 *$ & 0.0007 & 0.0010 & 0.0007 \\
\hline $\mathrm{Pb}$ & 0.0366 & 0.0487 & 0.0146 & 0.0863 & 0.1435 & 0.0120 \\
\hline
\end{tabular}

$* \mathrm{p}<0.05$

\section{Discussion}

The association between exposure to PM exposure and the individual components of MetS such as: Hyperglycemia, hypertension, high triglycerides, obesity and low HDL has been well documented in literature ( $\mathrm{Li}$, et al., 2013; Roberts, et al., 2014; Rizzo, et al., 2014; Wang, et al., 2014; Fleisch, et al., 2014 and Pope, et al., 2015) . However, studies relating MetS per se with PM exposure are scarce. The $28.3 \%$ overall prevalence of MetS in Saudi Arabia was attributed to risk factors including males, increasing age, lower education, higher income, smoking, and sedentary life style (Aljohani, 2014).

In the present study, MetS was found to be significantly more prevalent among Al Nuzlah subjects reaching $49.0 \%$. The role of usual isk factors for MetS seems to be minimal, since no significant differences could be detected in age, obesity, smoking, educational level, sedentary life style, and food consumption between the two populations studied. The higher levels of total $\mathrm{PM}_{2.5}$ and not $\mathrm{PM}_{10}$ in $\mathrm{Al}$ Nuzlah support the idea of a possible role of PM exposure in the onset of MetS. It has been 
suggested that $\mathrm{PM}_{2.5}$ is more harmful to health than $\mathrm{PM}_{10}$, because they can penetrate deeper in lungs (Churg and Brauer, 2000). Recent literature reported a positive association between exposure to PM and MetS (Eze, et al., 2015 and Brook, et al., 2016).

The toxicity of PM depends largely on its components. As endocrine disrupting chemicals, heavy metals and metalloids were found to play a role in the onset of MetS. Genetic factors and mitochondrial dysfunction could be the underlying mechanism (Sun, et al., 2012; Brocato, et al., 2014 and Kim and Lee, 2014). Moreover, a synergistic effect of a mixture of metals on the prevalence of MetS in the general population has been detected (Moon, 2014). The present study revealed significantly higher levels of nickel and cadmium in the PM of Al Nuzlah district, where MetS was more prevalent.

Nickel as being a key player in the adverse health effects associated with PM exposure has long been reported. Cardiovascular disease (Ying, et al., 2013 and Bell, et al., 2014), insulin resistance (Xu, et al., 2012) and MetS have been associated with nickel exposure (Yang, et al.,2014). It was proved that exposure to nickel and PM from Saudi Arabia at the same dose dysregulated the same MetS-genes (Brocato. et al., 2014, 2015).

Recent studies showed an association of blood cadmium concentration with MetS (Lee and Kim, 2013, 2015 and Han, et al., 2015). The pathological mechanism by which cadmium exposure may lead to MetS remains uncertain. Insulin resistance (Kawakami, et al., 2010) and heme catabolism (Satarug and Moore, 2012) were suggested as underlying characteristics of cadmium-associated MetS.

In conclusion, the present study adds more evidence that besides the role of life style, exposure to particulate matter must be considered an additional risk factor in the development of MetS.

The author acknowledges some limitations. The study is cross sectional in nature and hence causal relationships could not be ascertained. Self-reporting bias in lifestyle practices such as diet, smoking habits and physical activity may have affected the results.

\section{References}

Akbar, T. (2002) Metabolic syndrome is common in Saudi type 2 diabetic patients, Diabetes Int. 12: 47-9.

Albert, K., Eckel, R., Grundy, S., Zimmet, P., Cleeman, J., Donato, K. et al. (2009) Harmonizing the metabolic syndrome: a joint interim statement of the International Diabetes Federation Task Force on Epidemiology and Prevention; National Heart, Lung and Blood Institute; American Heart Association; World Heart Federation; International Atherosclerosis Society; and International Association for the Study of Obesity, Circulation 120: 1640-45.

Alberti, K.G., Zimmet, P. and Shaw, J. (2005) The metabolic syndrome: A new worldwide definition, Lancet, 366: 1059-62.

Al-Daghri, N., Al-Attas, O., Alokail, M., Alkharfy, K., Sabico, S. and Chrouso, G. (2010) Decreasing prevalence of full metabolic syndrome but a persistently high prevalence of dyslipidemia among adult Arabs, PLoS One, 5: e12159.

Aljohani, N. (2014) Metabolic syndrome: Risk factors among adults in Kingdom of Saudi Arabia, J. Family Community Med., 14; 21 (3): 170-175.

Al-Nozha, M., Al-Khadra, A., Arafah, M., Al-Maatouq, M., Khalil, M., Khan, N., et al. (2005) Metabolic syndrome in Saudi Arabia, Saudi Med. J. J26: 191825.

Al-Qahtani, D. and Imtiaz M. (2005) Prevalence of metabolic syndrome in Saudi adult soldiers, Saudi Med. J., 26: 1360-6.

Al-Qahtani, D., Imtiaz, M., Saad, O. and Hussein, N. (2006) A comparison of the prevalence of metabolic syndrome in Saudi adult females using two definitions, Metab. Syndr. Relat. Disord., 4: 204-14.

Al-Zahrani, A., Karawagh, A., Al-Shahrani, F., Naser, T., Ahmed, A. and Al-Sharee, A. (2012) Prevalence and predictors of metabolic syndrome among healthy Saudi adults, Br. J. Diabetes Vasc. Dis., 12: 78-80.

Araujo, J. and Nel, A. (2009) Particulate matter and atherosclerosis: role of particle size, composition and oxidative stress, Part. Fibre Toxicol., 6, 24. 
Aslam, M., Asif, M. and Altaf, S. (2011) Estimation of smoking index for male smokers in Multan city, Pak. J. Nutr., 10: 80-85.

Bahijri, S. and Al-Raddadi, R. (2013) The importance of local criteria in the diagnosis of metabolic syndrome in Saudi Arabia, Ther. Adv. Endocrinol. Metab., 4: 51-9.

Bahijri, S., Al-Raddadi, R., Jambi, H., Alaama, M. and Ferns, G. (2013) The prevalence of metabolic syndrome in an apparently health, normotensive and non-diabetic population in Saudi Arabia by two definitions: implications of local practice, Open $J$. Endocr Metab., 3: 18-24.

Barrimah, I., Mohaimeed, A., Hidhat, F. and Al-Shobili, H. (2009) Prevalence of metabolic syndrome among Qassim University personnel in Saudi Arabia, Int. J. Health Sci. (Qassim), 3: 133-42.

Bell, M. (2012) HEI Health Review Committee. Assessment of health impacts of particulate matter characteristics, Res. Rep. Health Eff. Inst., 161: 5-38.

Bell, M., Ebisu, K., Leaderer, B., Gent, J., Lee, J., Koutrakis, P., Wang, Y., Dominici, F. and Peng, R. (2014) Associations of $\mathrm{PM}_{2.5}$ constituents and sources with hospital admissions: Analysis of four counties in Connecticut and Massachusetts (USA) for persons \&gt; $/=65$ years of age, Environ Health Perspect., 122: 138-144.

Brocato, J., Harnandez, M., Laulicht, F., Sun, H., Shamy, M., Alghamdi, M., Khoder, M., Kluz, T., Chen, L. and Costa, M. (2015) In vivo exposures to particulate matter collected from Saudi Arabia or nickel chloride display similar dysregulation on metabolic syndrome genes, J. Toxicol. Environ. Health Part A., 78: 14211436.

Brocato, J., Sun, H., Shamy, M., Kluz, T., Alghamdi, M., Khoder, M., Chen, L. and Costa, M. (2014) Particulate matter from Saudi Arabia induces genes involved in inflammation, metabolic syndrome and atherosclerosis, J. Toxicol. Environ. Hlth., Part A, 77: 751-766.

Brook, R., Sun, Z., Brook, J., Zhao, X., Ruan, Y., Yan, J., Mukherjee, B., Rao,X., Duan, F., Sun, L., Liang, R., Lian, H., Zhang, S., Fang, Q., Gu, D., Sun, Q., Fan, Z. and Rajagopalan, S. (2016) Extreme air pollution conditions adversely affect blood pressure and insulin resistance: The air pollution and cardiometabolic disease study, Hypertension (ahead of print).

Chen, J.C. and Schwartz, J. (2008) Metabolic syndrome and inflammatory responses to long-term particulate air pollutants, Environ Health Perspect., 116: 612-617.

Chen, H., Burnett, R., Kwong, J., Villeneuve, P., Goldberg, M., Brook, R., van Donkelaar, A., Jerrett, M., Martin, R., Kopp, A., Brook, J. and Copes, R. (2013a) Spatial association between ambient fine particulate matter and incident hypertension, Circulation, 67 (1): 77-85.

Chen, H., Burnett, R., Kwong, J., Villeneuve, P., Goldberg, S., Brook, R., van Donkelaar, A., Jerrett, M., Martin, R., Brook, J. and Copes, R. (2013b) Risk of incident diabetes in relation to long-term exposure to fine particulate matter in Ontario, Canada, Environ. Health Perspect, 121: 804-10.

Chuang, K., Chan, C., Su, T., Lee, C. and Tang, C. (2007) The effect of urban air pollution on inflammation, oxidative stress, coagulation, and autonomic dysfunction in young adults, Amer. J. Respir. Crit.Care Med., 4: 370-6.

Churg, A. and Brauer, M. (2000) Ambient atmospheric particles in the airways of human lungs, Ultrastruct. Pathol, 24 (6): 353-361.

De Coster, S. and van Labereke, N. (2012) Endocrinedisrupting chemicals: associated disorders and mechanisms of action. J. Environ. Public Health 2012: 713696.

De Mattia, G., Bravi, M., Laurenti, O., et al. (2008) Endothelial dysfunction and oxidative stress in type 1 and type 2 diabetic patients without clinical macrovascular complications, Diabetes Res. and Clin. Practice, 79: 337-42.

Eze, I., Schaffner, E., Foraster, M., Imboden, M., von Eckardstein, A., Gerbase, M. Rothe, T., Rochat, T., Kunzli, N., Schindler, C. and Probst-Hensch, N. (2015) Long-term exposure to ambient air pollution and metabolic syndrome in adults, PLOS ONE, 10 (6): e0130337.

Fleisch, A., Gold, D., Rifas-Shiman, S., Koutrakis, P., Schwartz, J., Kloog, I., Melly, S., Coull, B., Zanobetti, A., Gillman, M. and Oken, E. (2014) Air pollution exposure and abnormal glucose tolerance during pregnancy. The project Viva cohort, Environ. Health Perspect, 122: 378-383.

Furukawa, S., Fujita, T., Shimakuburo, M., et al. (2004) Increased oxidative stress in obesity and its impact on metabolic syndrome, J. Clin. Invest., 114: 1752-61.

Ghio, A., Carraway, M. and Madden, M. (2012) Composition of air pollution particles and oxidative stress in cells, tissues, and living systems, J. Toxicol. Environ. Health Part B, 15: 1-21.

Gonzalez, R., Torres-Aviles, F., Carrasco, P., Salas, P. and Perez, B. (2013) Association of the incidence of type 1 diabetes mellitus with environmental factors in Chile during the period 2000-2007, Rev. Med. Chil., 141: 595-601.

Han, S., Ha, K., Jeon, J., Kim, H. Lee, K. and Kim, D. (2015) Impact of cadmium exposure on the association between lipopolysaccharide and metabolic syndrome, Int. J. Environ. Res. Public Health, 12: 11396-11409. 
Hutcheson, R. and Rock, P. (2012) The metabolic syndrome, oxidative stress, environment, and cardiovascular disease: the great exploration. Exper. Diabetes Res. http://dx.doi.org/10.1155/2012/271028.

Kawakami, T., Sugimoto, H., Furuichi, R., Kadota ,Y., Inoue, M., Setsu, K., Suzuki, S. and Sato, M. (2010) Cadmium reduces adipocyte size and expression levels of adiponectin and Peg1/Mest in adipose tissue, Toxicology, 267: 20-26.

Kim, J. and Lee, H. (2014) Metabolic syndrome and the environmental pollutants from mitochondrial perspectives, Rev. Endocr. Metab. Disord., 15: 253262.

Lee, B. and Kim, Y. (2013) Blood cadmium, mercury, and lead and metabolic syndrome in South Korea: 20052010 Korean National Health and Nutrition Examination Survey data, Am. J. Ind. Med., 56 (6): 682-692.

Lee, B. and Kim, Y. (2015) Association of blood cadmium level with metabolic syndrome after adjustment for confounding by serum ferritin and other factors: 2008 2012 Korean National Health and Nutrition Examination Survey, Biol. Trace Elem. Res. (ahead of print).

Li, R., Nayab, M., Pakbin, P., Ning, Z., Navab, K., Hough, G., Morgan, T., Finch, C., Araujo, J., Fogelman, A., Sioutas, C. and Hsiai, T. (2013) Ambient ultrafine particles alter lipid metabolism and HDL anti-oxidant capacity in LDLR-null mice, J. Lipid Res., 54: 16081615.

Lindsay, R.S. and Howard, B.V. (2004) Cardiovascular risk associated with the metabolic syndrome, Curr. Diab. Rep., 4: 63-8.

Maciejczyk, P. and Chen, L. (2005) Effects of subchronic exposures to concentrated ambient particles (CAPs) in mice: II. The design of a CAPs exposure system for biometric telemetry monitoring, Inhal. Toxicol., 17: 189-197.

Montero, D., Walther, G., Perez-Martin, A., Roche, E. and Vinet, A. (2012) Endothelial dysfunction, inflammation, and oxidative stress in obese children and adolescents: markers and effect of lifestyle intervention, Obes. Rev., 13: 441-55.

Moon, S. (2014) Additive effect of heavy metals on metabolic syndrome in the Korean population: the Korea National Health and Nutrition Examination Survey (KNHNES) 2009-2010, Endocrine, 46: 263-271.

Park, S., Auchincloss, A., O’Neill, M., Prinead, R., Correa, J., Keeler, J., Graham Barr, R., Kaufman, J. and Diez Roux, A. (2010) Particulate air pollution, metabolic syndrome, and heart rate variability: the Multi-Ethnic Study of Atherosclerosi (MESA). Environ. Health Perspect. 118: 1406-11.
Pelucchi, C., Negri, E., Talamini, R., Levi, F., Giacosa, A., Crispo, A., Bidoli, E., Montella, M., Franceschi, S. and La Vecchia, C. (2010) Metabolic syndrome is associated with colorectal cancer in men, Eur. J. Cancer, 46: 1866-72.

Pope, C., Turner, M., Burnett, R., Jerett, M., Gapstur, S., Diver, W., Krewski, D. and Brook, R. (2015) Relationships between fine particulate air pollution, cardiometabolic disorders, and cardiovascular mortality, Circ. Res., 116: 108-115.

Rizzo, A., Corsetto, P., Farina, F., Montorfano, G., Pani, G., Battaglia, C., Sancini. G. and Palestini, P. (2014) Repeated intratracheal instillation pf $\mathrm{PM}_{10}$ induces lipid reshaping in lung parenchyma and in extrapulmonary tissues. PLOS ONE 9:e106855.

Roberts, J., Voss, J. and Knight, B. (2014) The association of ambient air pollution and physical inactivity in the United States. PLOS ONE 9:e90143.

Rosato, V., Zucchetto, A., Bosetti, C., Dal Maso, L., Montella, M., Pelucchi, C., Negri, E., Franceschi, S. and La Vecchia, C. (2011) Metabolic syndrome and endometrial cancer risk, Ann. of Oncol., 22: 884-9.

Satarug, S. and Moore, M. (2012) Emerging roles of cadmium and heme oxygenase in type-2 diabetes and cancer susceptibility, Tohoku J. Exp. Med., 228: 267288.

Sun, H., Shamy, M., Kluz, T., Munoz, A., Zhong, M., Laulicht, F., Alghamdi, M., Khoder, M., Chen, L. and Costa, M. (2012) Gene expression profiling and pathway analysis of human bronchial epithelial cells exposed to airborne particulate matter collected from Saudi Arabia, Toxicol. Appl. Pharmacol., 265: 147-57.

Suzuki, T., Hirata. K., Elkind, M.C., et al. (2008) Metabolic syndrome, endothelial dysfunction, and risk of cardiovascular events: the Northern Manhattan study (NOMAS). American Heart J. 156: 405-10.

Wang, D., Strandgaard, S., Iversen, J. and Wilcox, C. (2009) Asymmetric dimethylarginine, oxidative stress, and vascular nitric oxide synthase in essential hypertension, Am. J. Physiol., 296: R195-R200.

Wang, B., Xu, D., Jing, Z., Liu, D., Yan, S. and Wang, Y. (2014) Effect of long term exposure to air pollution on type 2 diabetes mellitus risk: A systemic review and meta-analysis of cohort studies, Eur. J. Endocrinol., 171: R173-R182.

Ward, N., Hodgson, J., Puddey, I., Mori, T., Beilin, L. and Croft, K. (2004) Oxidative stress in human hypertension: association with antihypertensive treatment, gender, nutrition, and lifestyle, Free Radic.Biol.Med., 36: 226-32.

Xu, X., Rao, X., Wang, T., Jiang, S., Ying, Z., Liu, C., Wang, A., Zhong, M., Deiuliis, J., Maiseyeu, A., Rajagopalan, S., Lippman, M., Chen, L. and Sun, 
Q. (2012) Effect of co-exposure to nickel and particulate matter on insulin resistance and mitochondrial dysfunction in a mouse model, Part. Fibre Toxicol., 5, 9.

Yang, A., Bai, Y., Pu, H., Zheng, T., Cheng, N., Li, J., Zhang, Y., Ding, J., Su, H., Ren, X. and Hu .X. (2014) Prevalence of metabolic syndrome in Chinese nickel-exposed workers, Biomed. Environ Sci., 27 (6): 471-477.

Ying, Z., Xu, X., Chen, M., Liu, D., Zhong ,M., Chen, L., Sun, Q. and Rajagopalan, S. (2013) A synergistic vascular effect of airborne particulate matter and nickel in a mouse model, Toxicol. Sci., 135: 72-80.

Zanobetti, A., Franklin, M., Koutrakis, P. and Schwartz, J. (2009) Fine particulate air pollution and its components in association with cause-specific emergency admissions, Environ. Health, 8, 58.

Zelzer, S., Fuchs, N., Almer, G., et al. (2011) High density lipoprotein cholesterol level is a robust predictor of lipid peroxidation irrespective of gender, age, obesity and inflammatory or metabolic biomarkers, Clinica Chimica Acta, 412: 1345-9. 


\title{
التعرض للجسيمات المحمولة في الهواء: عامل خطر إضافي ل لمتلازمة الأيض في السعودية
}

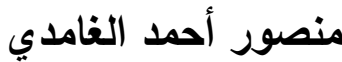

\author{
قسم العلوم البيئية، كلية الأرصاد والبيئة وزراعة المناطق الجافة، \\ جامعة الملك عبدالعزيز، جذة، المعلكة العربية السعودية
}

الستخلص. نتكل متلازمة الأيض مشكلة خطيرة في السعودية. ونسبت المشكلة إلى نمط الحياة. يعتبر التعرض للجسيمات الحمولة في الهواء في جدة موضوعًا مثيرًا للاهتمام. وقد هدفت الدراسة الحالية إلى إيجاد علاقة محتملة بين انتشار متلازمة الأيض ومسنويات الجسيمات والعناصر المكونة

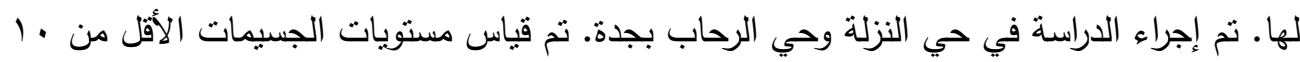
ميكرون والجسيمات الأقل من ب,0 ميكرون والعناصر الموجودة فيها. وقد اشترط لتعريف متلازمة الأيض نواجد الثلاث عناصر التالية: زيادة نسبة السكر في الدم، وارتفاع ضغط الدات الدم، والبدانة. وقد

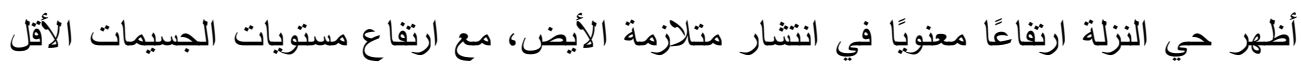

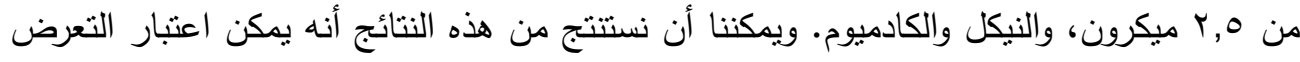
للجسيمات عامل خطر إضافي للإصابة بمتلازمة الأيض. 
